\title{
Chapter 9 \\ Regulation and Permitting of Standalone and Co-located Open Ocean Aquaculture Facilities
}

\author{
John S. Corbin, John Holmyard and Scott Lindell
}

\begin{abstract}
Aquaculture will be the dominant producer of global seafood in the 21st Century and the emerging open ocean farming sector must play an important role. Current concepts for utilizing the ocean for aquaculture in national Exclusive Economic Zones, include; standalone structures for growing shellfish and finfish and aquaculture production facilities co-located with other, compatible ocean uses, e.g., offshore oil platforms and wind energy towers. There may also be potential for multiple use of marine space incorporating aquaculture at different trophic levels together with artificial reefs, recreational angling and diving and commercial fishing using static gear. This chapter examines the global status of open ocean aquaculture (OOA), stand alone and co-located projects, in national ocean jurisdictions. Regulatory regimes and experiences permitting OOA shellfish and finfish farming in the United States and shellfish farming in the United Kingdom are shared. Examples of the permitting process from several U. S. states are also cited. Finally, conclusions and recommendations are offered to assist nations in formulating and implementing regulatory systems to effectively facilitate commercial aquaculture development in the open ocean environment.
\end{abstract}

\subsection{Introduction}

The current world population of 7.2 billion is projected to increase by 1 billion over the next 12 years and reach 9.6 billion by 2050 (UNFAO 2014). With this steadily rising population pressure on the earth's resources, as well as its political systems, social structures, and food production alternatives, there are many challenges to

\footnotetext{
J.S. Corbin $(\square)$

Aquaculture Planning and Advocacy LLC, Kaneohe, HI, USA

e-mail: jscorbin@aol.com

J. Holmyard

Offshore Shellfish Ltd., Brixham, Devon, UK

S. Lindell

Biology Department, Woods Hole Oceanographic Institution,

MS 34, 104 Redfield Bldg., Woods Hole, MA, USA

(C) The Author(s) 2017

B.H. Buck and R. Langan (eds.), Aquaculture Perspective of Multi-Use Sites

in the Open Ocean, DOI 10.1007/978-3-319-51159-7_9
} 
reaching the goal of a sustainable planet (Brown 2009; Friedman 2008). Two of the most important challenges are sufficient food and sufficient energy; both from sustainable sources.

\subsubsection{Cultured Seafood Trends}

Fish provide $17 \%$ of world protein and for nearly 3 billion people and for 4.3 billion people $15 \%$ of their consumption (UNFAO 2014). It is well established that yields from capture fisheries have leveled off and future increases in seafood production must come from aquaculture. In 2012, humans consumed 136.2 Mmt of seafood and aquaculture (excluding aquatic plants) provided $66.6 \mathrm{Mmt}$ or $48 \%$. Current cultured supplies are dominated by freshwater species (carps, tilapias, cyprinids, catfishes) and the marine species component (finfish, shellfish and crustaceans) makes up 36\% (UNFAO 2014).

Projections of future seafood demand pose a daunting target for producers in both developing and developed countries. Notably, besides relentless population growth driving increased demand, rising income levels are contributing to rising world per capita yearly seafood consumption, which has increased from $9.9 \mathrm{~kg}$ in the 1960 s to $19.2 \mathrm{~kg}$ in 2012 and this trend will continue (UNFAO 2014). Recent World Bank projections indicate "the most plausible scenario" for aquaculture expansion is by 2030 production will reach $93 \mathrm{Mmt}$, which is an increase over the 2012 value of $66 \mathrm{Mmt}$ of $27 \mathrm{Mmt}$ in only 15 years (World Bank 2013). Notably, aquaculture could supply more than $60 \%$ of fish for direct human consumption by this date, however the huge challenge can be portrayed as expanding production by more than the current size (1.3 Mmt) of Norway's highly successful 30 year old salmon industry each year going forward (Corbin 2010).

While there are many challenges for mariculture development to overcome, these seafood trends are focusing greater attention on expansion of coastal, offshore and open ocean farming and its environmental and resource advantages over land-based and inland water production (Lovatelli et al. 2013; Kapetsky et al. 2013). The vision for marine aquaculture, is becoming clear, but the legal and regulatory environment for offshore industry development is consistently cited as a major hurdle to expansion (Knapp 2013; Percy et al. 2013). Experts note the most important factors affecting successful growth will be the extent to which enabling regulatory frameworks establish clear, stable, and timely processes for permitting and regulating large-scale, ocean farming (Knapp 2013).

\subsubsection{Ocean Energy Trends}

The offshore environment of the continental shelf, including the deep ocean beyond the neritic/sub-littoral zones, is the location and potential location of important 
energy generation technologies; namely oil and natural gas drilling platforms and wind farms. As with the trend in marine aquaculture, ocean energy generation facilities are moving further offshore and offer opportunities for co-location of fish and shell fish farming.

Drilling for oil and gas in nearshore waters has been going on since the late 1800 s and as technologies improved and market forces increased demand, companies moved further and further offshore. Present day technologies are capable of operating in water depths up to $3000 \mathrm{~m}$ (AOGHS 2014). Worldwide as of February 2014 there were 1501 offshore oil and gas rigs deployed, with the highest concentrations in the Gulf of Mexico (229) and in the North Sea (180) (Statista 2014). While a projection of numbers of future drilling rigs is not available, it is forecast that the annual investment in rigs will grow from approximately $\$ 80$ billion dollars to over $\$ 120$ billion dollars in 2020 .

Wind energy farms have moved offshore as technology has become available to support renewable energy production in the harsh, exposed ocean environment. Today $4420 \mathrm{MW}$ of offshore wind power have been installed globally as of June 2012, representing $2 \%$ of total installed world wind power capacity. More than $90 \%$ of this capacity is installed off northern Europe, in the North Sea, Irish Seas and the English Channel. Expectations are that major new developments will be occurring in China, Japan, Korea, the United States, Canada, and Taiwan in the near future (GWEC 2014).

Current plans for locating more ocean wind farms around the world indicate the future of this form of renewable energy is very bright. According to the more ambitious projections a total of $80 \mathrm{GW}$ of offshore wind power could be installed world-wide by 2020, with three quarters located in Europe (GWEC 2014).

\subsection{Status of Commercial Offshore Aquaculture}

Aquaculture is the fastest growing food production technology in the world, though rates have been decreasing in recent years (UNFAO 2014). As a greater diversity of marine species became available from advances in husbandry techniques and sturdier growout technologies (e.g., anchored cages, net pens, and long lines), the industry has begun to utilize the offshore environment (Forster 2013; Jeffs 2013). But, what is a widely accepted definition of offshore aquaculture?

Recently the UNFAO Aquaculture Office held a workshop to comprehensively review the status and potential of offshore aquaculture and addressed this question among others (Lovatelli et al. 2013). Marine aquaculture in the ocean was operationally classified into three categories based on site characteristics; Coastal, Off-the-Coast, and Offshore. They can be defined as follows:

(1) Coastal aquaculture-Operations less than $500 \mathrm{~m}$ from the coast and in protected or semi-protected waters-less than $90^{\circ}$ exposure to the open ocean. Water depth is less than $10 \mathrm{~m}$. These facilities can be accessed $100 \%$ of the 
time. This category is not the main focus of this discussion, though contrasts between this category and the others will be made.

(2) Off-the-Coast aquaculture - Operations that are $500 \mathrm{~m}$ to $3 \mathrm{~km}$ from the coast. Generally, they are within the Continental Shelf zone or open ocean and with water depths of 10-50 m and wave heights of less than 3-4 m. These locations are exposed greater than $90^{\circ}$ to the open ocean and include some automation to operate.

(3) Offshore aquaculture-Operations located greater than $2 \mathrm{~km}$ or out of sight from the coast, in water depths greater than $50 \mathrm{~m}$, with wave heights of $5 \mathrm{~m}$ or more, ocean swells, variable winds and strong currents. These locations are exposed equal to or greater than $180^{\circ}$ to the open sea and there is a great need for automation of these remote operations (Lovatelli et al. 2013).

These discussions focus on off-the-coast and offshore locations for standalone and co-located aquaculture farms. The term open ocean will be used when both locations are being discussed.

\subsubsection{Standalone Aquaculture Projects}

Standalone commercial aquaculture in off-the-coast and offshore environments is an emerging activity in many countries that have a history of land-based and coastal marine aquaculture development. As a result, off-the-coast farming technology is evident in many developed countries and is being touted in developing countries for expansion of fish production. Moreover, while offshore technology has been proven technically feasible, it's wide spread application has been slow due to the significant logistical, technical and economic challenges of operating a farm at a site exposed to open ocean winds, waves and currents (Lovatelli et al. 2013).

A recent study of the status and potential of global offshore mariculture from a spatial perspective (suitable area) utilizing nations with existing industry is instructive. Between 2004 and 2008, 93 nations produced an average yearly production of $30 \mathrm{Mmt}$, with a mean of 15 tonnes $/ \mathrm{km}$ of coastline and a median value of 1 tonne $/ \mathrm{km}$, indicating a few large producers and many small ones. The maximum observed value was 520 tonnes $/ \mathrm{km}$. About half the 93 producing nations have production of less than 1 tonne/km of coastline (Kapetsky et al. 2013).

Indicative of potential, 80 of these producing nations have a total coastline length of $1,472,111 \mathrm{~km}$, while at present $44 \%$ of maritime nations with 0.3 million $\mathrm{km}$ of coast line are not practicing mariculture. Nations with the greatest long-term development potential based on coastline length are Canada, Indonesia, and Chile. Nations with the greatest long-term potential based on area of their EEZ are Russia, the United States and France (Kapetsky et al. 2013).

Most of temperate water marine fish production in ocean locations is located in Northern Europe (40\%), followed by South America (27\%); with Norway and Chile dominating. Atlantic salmon is the dominant fish, with Norway the largest 
producer followed by Chile. The next most important species are Sea Bream and Sea Bass, with China being the largest producer followed by Mediterranean Sea countries, with Greece as the largest producer. For shellfish (largely oysters and mussels), the dominant producers are the Republic of Korea, Japan, and Spain, followed by much smaller production from France, Chile, and the United States (Holmer 2013).

The majority of tropical offshore aquaculture activity is concentrated in two regions, Asia and tropical locales of the Caribbean and Hawaii-USA. Off-the-coast and offshore aquaculture in Asia are dominated by China, with 900 cages growing cobia, amberjack, sea bream, and other economically important species. Deep water offshore cages were initiated in China in the late 1990s and expansion has continued as a government priority in the coastal provinces with suitable climate (Angel and Edelist 2013).

Hawaii-U.S.A. and the tropical locales of Puerto Rico, the Bahamas, Panama, Belize, Mexico, and Costa Rica all have had large-scale research, pilot projects and several commercial scale projects (Panama currently boosts the largest open ocean farm in the world), with cobia as the most popular species in the Gulf of Mexico and the Caribbean (Alston et al. 2005; Angel and Edelist 2013; Open Blue Sea Farms 2014). In October 2014, Hubbs Sea World Research Institute (HSWRI) began the permit process to locate a 5000 tonne fish farm for Pacific yellowtail 4.5 miles off Southern California, USA; which if successful will be the first commercial fish farm in federal waters (Leschin-Hoar 2014).

\subsubsection{Aquaculture Co-located with Platforms}

The concept of co-locating commercial farms with established and emerging open ocean private sector activities, that is ocean wind farms and oil and gas drilling, has come to the fore front in recent years (Bridger 2004; Buck et al. 2004). A perceived major advantage of co-location is that the much needed energy generating activities have an existing regulatory framework that may be utilized for siting aquaculture and that permitting/leasing mechanisms are lacking or poorly developed for open ocean aquaculture in most countries (Holmer 2013).

More practical considerations in the case of utilizing wind farms include: the massive platforms to attach aquaculture equipment and the unused space between the turbines for aquaculture that could have restricted public access and enhanced security. In the case of oil and gas drilling structures, active or decommissioned, there is a large structure to attach farm equipment and more importantly with decommissioned rigs, there is unused deck space on the platform for fish tanks and support activities. Also important, with oil and gas platforms, the energy company would not have to go to the expense and could avoid the environmental disruption of dismantling the platform by fostering an ongoing beneficial use.

While strong analytical arguments have been made for incorporating aquaculture into the planning of wind farms and to some extent oil and gas platforms, actual 
demonstrations are few and small scale (Buck et al. 2004; Bridger 2004; Mee 2006). Cultivation of seaweed and blue mussels have been demonstrated to be biologically and technically feasible in the high energy ocean environment of the North Sea (Buck et al. 2004, 2008). In addition, conceptualization of aquaculture systems that can utilize wind farm infrastructure and adjacent areas is well along (AWI 2014; Lagerwald et al. 2014).

In the US, a pilot demonstration shellfish farm associated with a large, offshore wind farm off Cape Cod, State of Massachusetts, was recently approved and is discussed in the following section. In Europe, in recent years, numerous successful co-location trials have been carried out using blue mussels and assorted other species (Lagerwald et al. 2014).

Co-location of aquaculture research and pilot demonstration projects with oil and gas ocean infrastructure began in the US in the mid-1990s. The first aquaculture facility associated with the industry was the SeaFish project in 1998, located 34 miles off of the State of Texas. SeaFish operated for one year, growing red drum, but ended in 1999 when Shell Oil decided to reactivate the platform.

The second major co-location project was planned for Platform Grace in federal waters 10.5 miles off Ventura, California, USA which stopped producing oil and gas in 1997. Recognizing the opportunity, HSWRI, a prominent US aquaculture research institute, leased the facility in August, 2003 for a project to culture shellfish and a variety of native finfish (HSWRI 2003; Krop and Polefka 2007). In 2004, the agreement with HSWRI was not renewed by Venoco and the company resumed oil and gas production shortly thereafter.

With the rising interest in offshore aquaculture, in 2007 the Minerals Management Service (MMS) that manages all offshore U.S. oil and gas leasing (now the Bureau of Ocean Energy Management, Regulation and Enforcement), approved a program for the outer continental shelf to issue leases, easements, and rights of way for alternative uses of offshore oil and gas production platforms. MMS could authorize individual projects and offshore aquaculture is identified as one of the activities.

\subsection{Case Studies on Permitting and Regulation}

\subsubsection{Introduction}

Commercial offshore aquaculture will not fully develop unless governments create a supportive political climate and resulting regulatory conditions. More specifically, a recent study of the offshore industry from an economic perspective concluded:

Offshore aquaculture will develop only where there is an enabling regulatory framework which allows investors to undertake projects with a reasonable expectation that their investments in the farm and their fish will be secure and a reasonable degree of certainty about how the operation will be regulated (Knapp 2013). 
A wide variety of government policies may affect the development of offshore aquaculture. However, required investment will not occur without policies which give fish farmers the opportunity and the incentive to invest (Knapp 2013). Some of the most important policies can be grouped broadly under two categories: Regulatory and Leasing (Table 9.1). Under regulatory policies the most important concerns for industry are: number and complexity of the regulations; predictability of the process of obtaining permits; and costs of compliance. Under leasing policies the most relevant concerns are: complexity and predictability of the leasing process; how legally secure is the site in terms of use, exclusive use and property rights; and the available length of lease and predictability/stability of the cost (rent/royalties) (Percy et al. 2013).

Percy et al. (2013) provides a succinct discussion of the purposes of a permit/license/lease system for marine aquaculture (Table 9.2). The overarching principle is no person can carry on ocean farming without first obtaining a permit, license or lease from the government, be it national, state or local. The requirement confirms by law the government has the right to regulate aquaculture and prosecute those that violate the imposed requirements.

In particular, the requirement enables the government to directly regulate the operator of a facility to: enforce the accepted management concepts of aquaculture, protect the environment, restrict the location and number of facilities, and obtain public input on development (Table 9.2). These purposes should be kept in mind when reviewing the Case Studies.

International law distinguishes generalized sea areas and jurisdictions that serve as the framework for government's declaring control, ownership and authority to regulate off-the-coast and offshore ocean waters (Fig. 9.1). Moving out from the shore, there exists the following categories (Lovetalli et al. 2013).

Table 9.1 Selected government policy issues affecting offshore aquaculture development

\begin{tabular}{l|l}
\hline Category & Policy issues \\
\hline Regulatory policies & - What regulations does government impose? \\
& $\begin{array}{l}\text { - How costly are the regulations? } \\
\text { - What is the process for developing regulations? } \\
\text { - How stable and predictable are the regulations? } \\
\text { - What are the objectives of the regulations? } \\
\text { - How cost efficient are the regulations? }\end{array}$ \\
\hline Leasing policies & - Is there a process to lease offshore sites? \\
& - How predictable is the process? \\
& - How long does the process take? \\
& - How flexible are permitted uses? \\
& - Can sites be transferred? \\
\hline
\end{tabular}

Source adapted from Knapp 2013 
Table 9.2 Purposes of requirements for permits, licenses and leases to establish a regulatory framework for marine aquaculture
- Enable the government to assess the capacity of the applicant to carry out the project, e.g., aquaculture experience

- Show in advance how the applicant will meet all regulatory requirements

- Enable the government and others to identify all the other facilities by maintaining a register

- Provide a means of enforcing the basic rules applicable to an operation through the attachment of conditions

- Enable the government to control the numbers of operations issued to avoid excessive facilities concentration and supervise geographical distribution

- Use the application/approval process to obtain public input on the proposed operations

Source adapted from Percy et al. (2013)

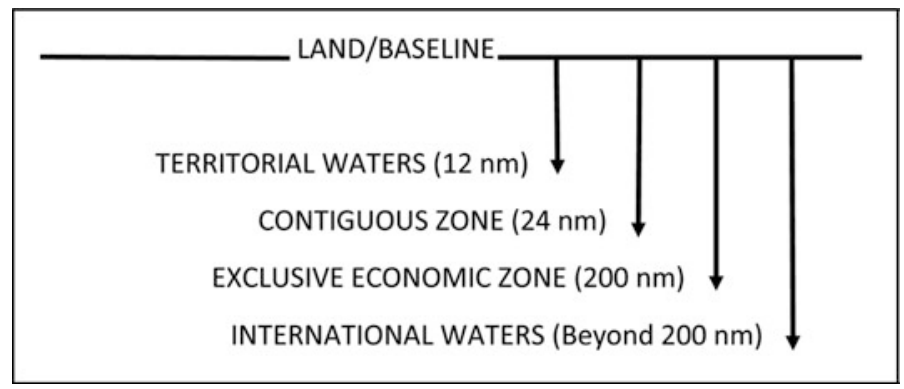

Fig. 9.1 Generalized sea areas and jurisdiction in international rights

- Baseline - the low-water line along the coast of a State (Country).

- State's Territorial Sea-extends up to $22 \mathrm{~km}$ (12 nm) from its baseline. The State has sovereignty over its territorial sea.

- Contiguous Zone - is a band of water extending from the outer edge of the territorial sea to up to $44 \mathrm{~km}(24 \mathrm{~nm})$ from the baseline, within which the State can exert limited control as in the territorial sea.

- Exclusive Economic Zone (EEZ) — extends from the outer limit of the territorial sea to a maximum of $370.4 \mathrm{~km}(200 \mathrm{~nm})$ from the territorial sea baseline and inclusive of the contiguous zone. A coastal State has control of all economic resources within the EEZ.

- International Waters (High Seas or Area Beyond National Jurisdiction (ABNJ)) are oceans, seas, and waters outside of national jurisdiction, i.e., beyond the EEZ.

These Case Study discussions of permitting and regulation will address off-the-coast and offshore aquaculture activities in the Territorial Sea, Contiguous Zone, and the EEZ; with the focus being the situations in the United States and United Kingdom. 
In the U.S., the ocean jurisdictions are defined somewhat differently with coastal states generally having jurisdiction from shore out to $3 \mathrm{~nm}$ (and a few states out to $12 \mathrm{~nm}$ ), so called State waters, and the national government having principal jurisdiction from $3 \mathrm{~nm}$ (or $12 \mathrm{~nm}$ ) out to $200 \mathrm{~nm}$, so called Federal waters. In the United Kingdom ocean jurisdictions reflect centuries of government ownership and administration of so called Crown Estate land and sea bed resources out to $12 \mathrm{~nm}$, however management in the nation's EEZ is not clear. By law Crown Estate resources belong to the reigning monarch, however they are not the monarch's private property, but are managed (e.g., leased for offshore aquaculture) by an independent entity, the Crown Estate to maintain and enhance the value and generate revenue for the UK treasury (Crown Estate 2014).

\subsubsection{Regulating Finfish Aquaculture in the U.S. EEZ, a Regional Approach}

The U.S. has had a National Aquaculture Plan since 1980, however growth has been primarily in land based, fresh water species, until the last decade (Anderson and Shamshak 2008). The 2012 US Aquaculture Census put the industry at 269,550 tonnes, valued at $\$ 1.233 \mathrm{~B}$. Mariculture species represent $37 \%$ of that value, and consist of primarily near shore, ocean culture of salmon and various mollusks, grown entirely in state waters (NMFS 2013).

US seafood imports has steadily risen to $91 \%$ of annual consumption, causing numerous government and public calls for expanding domestic supplies from aquaculture and particularly from marine aquaculture and farming the EEZ (e.g., PEW Ocean Comm. 2003; U.S. Commission on Ocean Policy 2004; U.S. Ocean Action Plan 2004; NOAA 10-year Plan for Marine Aquaculture 2007; PEW Marine Aquaculture Task Force 2007; NOAA Aquaculture Policy 2011; Department of Commerce Aquaculture Policy 2011). Clearly, there is a well-documented national policy to encourage commercial aquaculture in the EEZ to increase domestic supplies and help address the growing seafood security issue. Central to this policy is establishing the regulatory and legal framework to permit and manage aquaculture sustainably in federal waters (e.g., a permit and site administration process that provides for management, environmental monitoring, and enforcement and site tenure, exclusive use, and property rights and protections for the commercial projects) (Fletcher 2004).

From publication of the first National Aquaculture Plan to the present, regulatory constraints have been frequently cited as a major obstacle to U.S. industry expansion (Firestone et al. 2005; Stickney et al. 2006; GAO 2008; NOAA 2008). The regulatory framework for aquaculture in the EEZ is the least developed ocean jurisdiction and can best be described as nascent or a work in progress. There are two emerging approaches extant: 
(1) A region by region permitting process for certain federally regulated finfish species in the region that nominally exists, but is currently being fleshed out from an operational standpoint and remains untested, and

(2) An individual lead federal agency permitting process for shellfish (and possibly finfish) that is emerging and may be used to locate a commercial farm anywhere in federal waters (the next case study), though questions remain regarding its long-term viability.

This section addresses the regional approach to permitting commercial aquaculture in the EEZ. As background, the recent Congressional history of attempts to legislate an overarching national framework to site aquaculture in federal waters is described. Initial actions by the Regional Fishery Management Councils to plan and develop fish farming in the EEZ are highlighted. The permitting process formulated by the Gulf of Mexico Regional Fishery Management Council is described in detail. Finally, permitting and leasing processes successfully used in state waters by Maine and Hawaii for more than 15 years are briefly described to contrast with the federal effort.

\subsubsection{Background}

Legislation to establish a federal regulatory system that provides a comprehensive nationwide approach (not regional) for permitting and management of EEZ aquaculture was introduced by previous Administrations and members of Congress on numerous occasions over the past 10 years. Bills were introduced in the 2005, 2007, 2009, 2011 sessions and a bill was in preparation for the 2013 session, but was halted with the death of the author. In all instances, the National Oceanic and Atmospheric Administration (NOAA), U.S. Department of Commerce (USDOC) was the designated lead agency for national marine aquaculture research and development and specifically for implementing a permit process for commercial farming in the entire U.S. EEZ.

The general purpose of all the bills was three fold: (1) support the development of a sustainable marine offshore industry, (2) safeguard the marine environment and coastal communities, and (3) support research and development to further industry expansion. All the bills were comprehensive in structure and virtually all the measures included sections on: Definitions, Administration, Office of Sustainable Marine Aquaculture, Marine Aquaculture Research and Development, Offshore Aquaculture Permits, Prohibitions by Coastal States, Recordkeeping and Access to Information, Protections for Marine Environment, Unlawful Activities, Enforcement Provisions, Civil Enforcement and Permit Sanctions, Criminal Offenses, Forfeitures, Severability, and Judicial Review, and Authorization of Appropriations. For a bill example see the National Offshore Aquaculture Act of 2007 (GCFMC 2014b). None of these measures passed due largely to opposition by environmental groups (Non-Governmental Organizations) and sympathetic members of Congress (Jeffs 2013; Angel and Edelist 2013). 


\subsubsection{A Path Forward}

In the context of this highly political struggle to promulgate comprehensive, overarching legislation, the federal government improvised a path forward. The approach was to use America's cornerstone national legislation for regionally managing fisheries in federal waters, the Magnuson-Stevens Fishery Conservation and Management Act (MSA), though the Act does not specifically mention aquaculture. In 1993, NOAA legally defined marine aquaculture as fishing, under the authority of MSA, which allowed three possible approaches to developing fish farming in each of the eight regions defined in the Act: (1) Issuing an Exempt Fishing Permit of limited scope and duration, (2) Amending an existing Fisheries Management Plan (FMP) for a regulated species or ecosystem to include aquaculture, and (3) Developing a specific FMP for regulating offshore mariculture in the region.

Several of the Regions embraced NOAA's definition and increasing advocacy for marine aquaculture. The New England Regional Fishery Management Council established evaluation criteria for open ocean aquaculture proposals that dictated the use of best management practices aimed at reducing environmental and fishery impacts-one commercial scallop project has been permitted to date (Upton and Buck 2010). The Western Pacific Council developed and passed a detailed Aquaculture Policy Statement to encourage projects that comply with a set guidelines-NOAA has issued permits for two short-term research projects testing floating and deep water, anchored cages have been approved off Hawaii and they prompted a court case instigated by an out-of-state environmental group that up held the 1993 legal definition opinion. In addition, the Western Pacific Council has begun a process to amend all its Fishery Management Plans to permit issuance of permits for commercial aquaculture.

The Gulf of Mexico Council has been the most active in putting in place a detailed regulatory process for selected managed fish species in federal waters, but progress has been very slow. In 2003 the Council adopted an aquaculture policy for the Gulf EEZ. Recommendations were made in six key areas: (1) allowable species, (2) habitat protection, (3) research, (4) location and design, (5) water quality, and (6) health management and disease control (GMFMC 2014a).

This led the Council to undertake preparation of a Management Plan for aquaculture in federal waters of the Gulf, inclusive of a comprehensive Federal Programmatic Environmental Impact Statement (PEIS), Regulatory Flexibility Analysis and Regulatory Impact Review (GMFMC and NOAA 2009). The massive document, after public review, was adopted by the Council in January 2009 and was sent, as required, to the Secretary of Commerce for final review and approval. In an unprecedented move, the Secretary and NOAA allowed the Plan and PEIS to become law without agency approval because, "Offshore aquaculture activities should be governed by a comprehensive national policy rather than by regional regulatory frameworks." At the time NOAA indicated they would work on an overarching national policy with the Councils and Congress to ensure a smooth transition to a national approach for regulating offshore aquaculture (Balsinger 2009). 
National marine aquaculture policy statements by the Department of Commerce and NOAA emerged and were adopted in 2011. It is notable that the NOAA policy changed direction and supported a regional approach (rather than a national approach) and provided extensive regulatory and operational guidance to the Fishery Councils (NOAA 2011). Unfortunately, it took until 2014 for NOAA to draft and put out Rules to implement the Gulf Plan that the Agency has touted as the model for the other Councils. Many in the industry attribute this long delay to the key leadership positions in NOAA having environmental concerns with marine aquaculture in federal waters(not supported by science), as well as lobbying by anti-aquaculture NGO groups (Angel and Edelist 2013).

The comment period on the Proposed Rules closed on October 27, 2014 and at this writing no firm time table currently exists for adoption. Therefore, the Proposed Rules will be used as the basis for describing the regional regulatory framework and process being considered by the U.S. to regulate aquaculture in the EEZ. (Note to the Reader: During the preparation of this book NOAA adopted the Proposed Rule discussed in this Chapter on January 11, 2016. On Febuary 16, 2016 a broad coalition of environmental and fishery interest groups filed a law suit challenging the Rule, which stopped further implementation and will be adjudicated in 2017. See the website of the Gulf of Mexico Fishery Management Council for an update on the situation.)

\subsubsection{The Gulf Council Permit Process}

Adoption of the Proposed Rules for the Gulf Council Plan will put in place a permit process to allow commercial aquaculture of species regulated by the Council in the federal waters of the Gulf of Mexico. To highlight the major aspects of the proposed process, the following are discussed: core terms, application description, process description, consultation requirements, and operational and monitoring requirements. Those readers interested in more detail should go to the original documents (GMFMC and NOAA 2009; GMFMC 2014a).

\section{Core Terms}

There was much deliberation of the Plan and permit content by the Gulf Council and input from the public; namely the core terms of placing limits on annual production, species covered, the initial permit term and the renewal process, the permit costs, and the requirements to obtain an assurance bond sufficient for removal of the project.

These extended discussions were largely prompted by concerns raised by the environmental community and the Gulf fishing industry. Notably, it was recognized by the Council that changes would be needed as experience was gained and they included in the Plan an adaptive management mechanism that could allow changes to be made, e.g., to core Plan terms and the Rules (GMFMC and NOAA 2009). Core terms are highlighted: 
- Limits on Production-The limits placed on the amount of fish grown annually, termed Maximum Sustainable Yield and Optimum Yield to be consistent with fisheries terminology, was $29 \mathrm{M} \mathrm{kg}$ round weight. The amount represented the average landings of all marine species in the Gulf. The Council set production limits for individual farms at $5.8 \mathrm{M} \mathrm{kg}$ so there was a diversity of producers.

- Species Grown-Utilizing MSA to regulate offshore aquaculture requires the species cultured must be in the portfolio of native species managed by the Council. Native species not under Council management may be cultured without a NOAA permit. Both the Rules and the Plan expressly prohibit culture of genetically modified and transgenic animals.

- Site Size - There is no limit on the size of a farm site. But, sites have to be twice as large as the combined area of the allowable aquaculture systems (e.g., cages and net pens) to allow for best management practices such as the rotation of systems for fallowing.

- Method of Site Disposition and Terms-The disposition process uses a permit to gain site access. The term for an initial aquaculture permit, which is issued by NOAA, is 10 years. Renewal periods for projects in good standing are in 5 year increments with no limits on number.

- Cost of Permit-The permit cost was determined through a government formula that is aimed at administrative cost recovery. The initial permit fee is $\$ 10,000$ and a $\$ 1000$ fee would be assessed annually. Each 5 year renewal would cost $\$ 5000$. A permit is transferrable to a new owner.

- Bond for Facility Removal-The applicant is required to obtain an assurance bond sufficient to cover the costs associated with removing all components of the facility, including the stock. This is a precautionary step to reduce the potential for navigational hazards and environmental impacts if structures remain after the operation has terminated.

\section{Description of the Application}

- Required information includes: business, applicant and hatchery contact information; documentation of U.S. citizenship or resident alien status; a baseline environmental assessment of the proposed site (content requirements in preparation); a description of the geographic location and dimensions of the aquaculture facility and site; a description of equipment, allowable aquaculture systems, and methods to be used for growout; a list of species to be cultured and estimated production levels; a copy of an emergency disaster plan; and copies of currently valid Federal permits applicable to the proposed operation.

- The applicant is required to obtain an assurance bond sufficient to cover costs associated with removing all components of the facility, including cultured animals.

- The applicant is required to provide a document certifying that all broodstock or progeny of such broodstock were originally harvested from U.S. waters the Gulf of 
Mexico and were from the same population or sub-population where the facility is located, and no genetically modified or transgenic animals would be stocked.

- The applicant is required to provide a copy of the contractual agreement with a certified aquatic animal health expert. An expert is defined as a licensed doctor of veterinary medicine or a person who is certified by the American Fisheries Society, Fish Health Section, as a Fish Pathologist or Fish Health Inspector.

\section{Description of the Permit Process}

- Once the NOAA Regional Administrator (RA) has determined an application is complete, notification of receipt of the application is published in the Federal Register. Interested persons are given 45 days to comment and comments would be requested during public testimony at a Council meeting. The RA would notify the applicant in advance of any Council meeting to offer an opportunity to appear to support the application.

- After public comment ends, the RA would notify the applicant and the Gulf Council in writing of the decision to issue or deny the permit. Reasons the RA may deny a permit might include: failing to disclose material information; falsifying statements of material facts; the project poses a significant risk to marine resources, public health or safety; and issuing the permit would result in conflicts with established or potential oil and gas infrastructure, safe transit to and from infrastructure and future geological and geophysical surveys.

- The RA may consider revisions to the application made by the applicant in response to public comment before approving or denying the permit.

\section{Consultations}

- The RA will consult with the Bureau of Ocean Energy Management, Regulation and Enforcement, the Bureau of Safety and Environmental Enforcement, and other Federal agencies as appropriate, to address and resolve any conflicts in the use of the Outer Continental Shelf (OCS), with special emphasis on energy programs.

- Other federal agencies that will require consultation are: U.S. Fish and Wildlife Service, National Coastal Zone Management Program, National Historic Preservation Council, and the military (Navy and Coast Guard). In addition, adjacent states and selected state agencies may need to be contacted.

Operational and Monitoring Requirements

- Start Up-To ensure permits are used, permittees are required to place $25 \%$ of allowable aquaculture systems approved for use at a specific facility in the water at the permitted site within 2 years of permit issuance and cultured fish would be stocked at the site within 3 years of permit issuance. 
- Source Hatchery-Fingerlings and other juvenile animals obtained for growout at an aquaculture facility in the EEZ should only be obtained from a hatchery located in the U.S. All broodstock used for spawning at a hatchery supplying fingerlings or other juvenile animals should be certified by the hatchery owner as having been marked or tagged (e.g., dart or internal wire tag).

- Health Certificate-Prior to stocking fish the applicant should provide NMFS a copy of an animal health certificate signed by an aquatic animal health expert certifying the fish have been inspected and are visibly healthy and the source population tests negative World Organization of Animal Health (OIE) pathogens specific to the cultured species or additional pathogens identified in the National Aquatic Animal Health Plan. The process should be repeated with each new stocking event.

- Broodstock Collection-At least 30 days before each time a permittee or the permittee's designee intends to harvest broodstock from the Gulf, including state waters, they are required to submit a request for harvest to the RA. The request should include information on the number, size and species to be harvested, the methods, gear, and vessels used in capturing, holding, and transporting broodstock, the date and specific location of intended harvest, and the location of where the broodstock would be delivered. If the harvest is approved, the permittee would be notified by the RA and required to submit a report within 15 days of the date of harvest summarizing the number, size, and species harvested and the location where the broodstock were captured.

- Stock Genetics-NMFS may sample cultured animals to determine genetic lineage. If cultured animals. If cultured animals are determined to be genetically modified or transgenic, then NMFS would order the removal of all these cultured animals.

- System Evaluation-Aquaculture systems (e.g., cages or net pens) used for growing fish would be evaluated by the RA on a case-by-case basis. The structural integrity and ability of proposed systems to withstand physical stresses associated with major storm events (e.g., hurricanes) would be reviewed by the RA, using engineering analyses, computer and physical oceanographic models, or other required documentation.

- Risk Assessment - The RA will evaluate the potential risks of proposed aquaculture systems to Essential Fish Habitat, endangered or threatened species, marine mammals, wild fish stocks, public health, or safety. Any system approved for use should be marked with a minimum of one properly functioning locating device (e.g., GPS device) in the event that the allowable system is damaged or lost. In addition, the U.S. Coast Guard requires structures be marked with lights and signals to ensure compliance with private aids to navigation.

- Facility Separation-No aquaculture facility should be sited within $(3 \mathrm{~km})$ of another facility to minimize transmission of pathogens between facilities.

- Restricted Zone-A Restricted Zone will be established for each aquaculture facility to afford additional protection to an operation's equipment and systems, and increase safety by reducing potential encounters with fishing vessels. Restricted access zone boundaries should be clearly marked with a floating 
device, such as a buoy. No recreational or commercial fishing, other than aquaculture may occur in the restricted zone.

- Facility Access-Permittees are required to provide NMFS personnel and authorized officers access to their aquaculture facility and records in order to conduct inspections and determine compliance with applicable regulations.

- Facility Inspection-Permittees should inspect the aquaculture systems for entanglements or interactions with marine mammals, protected species, and migratory birds. The frequency of inspections will be specified by NMFS as a condition of the permit.

- Biologics, Pesticides, Drugs-Farms have to comply with all applicable U.S. Department of Agriculture (USDA), EPA, and Food and Drug Administration (FDA) requirements. Use of aquaculture feeds should be conducted in compliance with EPA feed monitoring and management guidelines.

- Notification of Harvest-NMFS should be notified $72 \mathrm{~h}$ prior to the intended time of landing. The landing notification would include the time, date, and port of landing.

- Crop Landing-Permittees participating in the aquaculture program are allowed to offload fish at dealers only between 6 a.m. and 6 p.m., local time. All fish landed would have to be maintained whole with heads and fins intact. Any cultured fish harvested and being transported should be accompanied by the applicable bill of lading through landing ashore and first point of sale.

- Reporting Requirements-Permittees are required to report to NMFS the following events: major escape events, e.g., escape of $10 \%$ of fish from one cage; findings of reportable pathogens; and entanglements or interactions with marine mammals, protected species or migratory birds. All these events have to be reported within $24 \mathrm{~h}$ of discovery. Permittees must also report any change in the hatchery source of fingerlings or use of a new animal drug.

- Compliance with Permits - Permittees have to monitor and report environmental assessment data to NMFS in accordance to procedures specified by NMFS. Applicants also have to comply with all monitoring and reporting requirements specified in their Environmental Protection Agency (EPA) and the U.S. Army Corps of Engineers (ACOE).

Sanctions and Denials

- Permit Revocation, Suspension and Modification-An aquaculture permit issued pursuant to the Gulf Plan and Proposed Rule may be revoked, suspended, or modified in accordance with general procedures governing enforcementrelated permit sanctions found in sub part D of 15 Code of Federal Regulations part 904. Further denial of submissions of initial permits and renewals are covered by this part of the law (CFR 2014).

- Review Process-Briefly, the process includes the following steps: (1) Notice of permit sanction or denial, (2) Opportunity for a hearing before the NOAA 
Regional Administrator, and (3) Final Administrative decision. Suspended permits may be reinstated when a sanction has been reinstated. In emergency situations to protect the marine resource, a Judge can order suspension of farming activities or other actions (CFR 2014).

\subsubsection{Other Required Permits}

In addition to the NOAA permit described above, there are two other major permits required to locate and operate a fish farm in federal waters: the Department of the Army (DA) Section 10 Permit issued by the ACOE District Office and the National Pollution Discharge Elimination System (NPDES) Permit, issued by the Regional Office of the EPA. According to the Gulf Plan and Proposed Rules, the sequence for the applicant securing all permits is to obtain the DA Section 10 Permit and the EPA NPDES Permit, then these documents must be presented to NOAA as the final step for the agency to issue the NOAA permit.

The ACOE and the EPA permits are briefly highlighted below and for more details see the appropriate references (APA 2011; IWGA 2014).

\section{DA Section 10 Permit, ACOE-}

- Purpose-The DA permit program was established to ensure that the navigational characteristics of U.S. coastal waters were not adversely affected by development. The jurisdiction originally extended only to structures in navigable waters, however with the passage of amendments to the Clean Water Act in 1972, the authority of ACOE was extended to include issuing permits for discharge of dredge or fill material in U.S. waters, including all federal waters.

- Applicability-Navigable waters are defined as those waters that are subject to the ebb and flow of the tides and/or are presently used, or were used in the past, or may be susceptible to use in interstate or foreign commerce. The ACOE can issue an individual permit an aquaculture facility in federal waters. Individual permits include standard permits and for less complex projects a Letter of Permission.

- The Section 10 DA permit is required for structures or work in navigable waters and such work includes: piers, boat docks, breakwaters, permanent moorings, and anchored aquaculture facilities. Maintenance and repair of existing structures is generally exempt from a permit.

- Issuance of a permit is based on a "public interest review" which evaluates the probable impacts of a project, including its cumulative impacts. The decision process requires a balancing of the reasonable benefits which can be expected to accrue from an activity against its reasonable detriments. The permit will have conditions governing the execution of the project. 
- Information Requirements - The DA permit requires the proposed work be described in sufficient detail so its potential impact on the affected environment can be fully evaluated. The information required is diverse and besides addressing navigation, it includes: consideration of such areas as: conservation, economics, historic values, water quality, aesthetics, coastal zone management, environmental concerns, safety, food production, fish and wildlife values, and the general needs and welfare of the people.

- Both a complete narrative description and detailed plans and drawings are needed. Strictly, an Environmental Assessment is not required, though a large-scale project may need one. Consultations are required with NOAA, the U.S. Fish and Wildlife Service, the Historic Preservation Council and the Coastal Zone Management Office of the nearest state. There is a public comment period of 30 days on the application.

\section{National Pollution Discharge Elimination System (NPDES), EPA}

- Purpose-The purpose of the NPDES permit is to protect the water quality of the U.S., and by regulating the discharge of wastewater from fixed point sources into surface waters, including wetlands, coastal waters and the EEZ. Fixed point sources include pipes, ditches, channels, etc. from which pollutants may be discharged. Ponds, tanks, offshore fish cages, or other similar aquaculture infrastructure are generally considered fixed point sources.

- Applicability - The NPDES permits applies to aquaculture systems, generally categorized as Concentrated Aquatic Animal Production Facility (CAAP). A CAAP means a hatchery, land-based fish farm, offshore fish farm or other facility which contains, grows or holds aquatic animals. There are statutory exemptions available for fish farms growing less than $9091 \mathrm{~kg}$ of cold water animals or $45,454 \mathrm{~kg}$ of warm water animals. Also, the EPA can designate any size facility a CAAP on a case by case basis.

- In general, EPA may create farm effluent limitations for a point source in federal waters by reference to three types of standards set in law: Effluent Limitation Guidelines (ELG), Water Quality Standards (WQS), and Ocean Discharge Criteria (ODC). Regardless, managing aquaculture in federal waters has not been an agency priority and EPA has not issued WQS for aquaculture that apply to federal waters to date and the current ODC's provide little guidance for aquaculture discharges (HLS et al. 2012)

- In 2004, EPA did establish ELG's for aquaculture, including net-pen facilities. The CAAP ELG's include only "narrative effluent limitations" requiring implementation of effective operational measures to achieve reduced discharges of solids and other materials in the CAAP waste waters, i.e., not numerical effluent limitations. To illustrate with two narrative limitations: (a) the employment of efficient feed management and feed input to the minimum amount reasonably necessary to achieve production goals and sustain targeted 
rates of aquatic animal growth and (b) that the production system be inspected on a routine basis in order to identify and promptly repair any damage and regular maintenance be employed in order to ensure that it is properly functioning.

- Facilities subject to the ELG's are required to develop and maintain a Best Management Practices (BMP) plan describing how they will achieve these and other requirements. In the absence of distinct ELG for the project, the law allows the permit writer to use "best professional judgment" to issue the permit (HLS et al. 2012). A permit is issued for a set time period of no more than five years and is renewable and transferrable.

- Information Required-In general, a project application must describe the proposed activity, including location, species, and number of animals, daily flow of effluent and infrastructure making up the facility. The physical-chemical nature of the effluent, including $\mathrm{pH}$, temperature, dissolved oxygen, nitrogen, and phosphorus, must be characterized. Further, it describes the receiving water and water source and total kilograms of food being fed during the calendar month of maximum feeding. Tests on the existing quality of the receiving water, a survey of the receiving water's ecosystem, and an analysis of the prevailing water currents may also be required.

\subsubsection{Successful State Permit/Leasing Processes}

Several U.S. states have supported offshore aquaculture in state waters for many years as a tool for economic development and diversification, particularly in rural, coastal areas. Two states among the leaders are Maine and Hawaii. It is beyond the scope of this chapter to detail the permitting processes to secure an offshore site in Maine and Hawaii, which include most of the same considerations as the regional permitting process under MSA, i.e., environmental impacts, multiple use conflicts, public participation, consultations with other agencies, and public safety, etc. These considerations allow the lead state agency to grant a use permit/lease, the ACOE District to grant a Section 10 permit and the state's water quality agency to grant an NPDES permit. Readers are referred to the appropriate web sites for details (APA 2011; IWGA 2014).

However, an important difference between the regional permit process as defined previously and these state processes is the property management vehicle to grant access to an aquaculture site is a lease and not a permit. Legal convention in the U.S. is a lease for property is needed to grant exclusive use, property rights and protections and tenure and is also important for the leasee to qualify for financing and insurance (Fletcher 2004; Firestone et al. 2005; Callies 2010; NSGLC 2012). The core aspects of the offshore aquaculture leasing programs in Maine and Hawaii are highlighted to contrast with the regional permit approach for federal waters being implemented by the Gulf. The aspects discussed are: limits on production, species that can be grown, size of the site, terms of the lease, cost of the lease, and bond requirements. 
Maine

Maine began leasing sheltered State offshore waters for salmon aquaculture in 1970. Shellfish was the primary species initially and then cage culture of salmon became a target. There are three different access vehicles to State waters for different purposes, described below (State of Maine 2014). Today Maine boosts one of the most valuable aquaculture industries in the U.S. valued at $\$ 57 \mathrm{M}$ in 2013. The Core Terms are highlighted as follows:

- Limits on Production-No limits are placed on volume of production, but there are limits on the size of the site that can be leased.

- Species Grown-For the Experimental Lease and the Standard Lease, any species already present in Maine. Bringing in out-of -state stock requires a State Department of Marine Resources import permit. With a Limited Purpose Aquaculture License (LPA) the species cultured can be blue mussels, clams, American and European oysters, sea and bay scallops, green sea urchins and marine algae.

- Site Size-Maximum size for a Standard Lease is 40 ha and for an Experimental Lease is four acres. For the LPA license it is up to 400 sq. $\mathrm{ft}$.

- Method of Site Disposition and Terms-A lease is the site disposition vehicle for an experimental project that can be up to 3 years and the large-scale, long-term commercial project that can be up to 10 years. A license mechanism is used for the short-term, one calendar year LPA project. Renewals are possible for the Standard Lease and LPA license for similar terms.

- Cost of the Lease-The Standard Lease costs \$1500 for shellfish and \$2000 for finfish, plus $\$ 100$ per acre per year rent. Renewal fees after 10 years are $\$ 1000$ for shellfish and $\$ 1500$ for finfish.

- Bond for Facility Removal-Both the Standard Lease and Experimental Lease require a bond for removal of the facility and crop if the lease is terminated. The LPA license does not require a bond.

\section{Hawaii}

Hawaii began leasing State marine waters for commercial aquaculture in 2001, with the first farm in the U.S. to be sited in open ocean conditions and operated totally submerged growing the Pacific Threadfin fish. This was followed shortly after by a second farm growing Amberjack (Sims 2013). Today Hawaii has one offshore fish farm and several in the permit process. Its total aquaculture industry was valued at $\$ 58 \mathrm{M}$ in 2013.

Obtaining an offshore site requires a two-step process. First the company must obtain a Conservation District Use Permit (CDUP) from the Department of Land and Natural Resources (DLNR), which is a conditioned permit that describes the site and the aquaculture use (State of Hawaii 2014). The CDUP application requires an Environmental Assessment be carried out. Upon approval of the use by DLNR, 
the applicant can then negotiate the terms of a long-term lease from DLNR for State marine waters (APA 2011; Sims 2013). The Core Terms are highlighted as follows:

- Limits of Production-No limits are placed on the volume of production, but the oceanographic characteristics of the site must support the proposed project.

- Species Grown-Any species native to Hawaii may be grown. If the species is subject to State regulations then a license for procession of the species must be obtained.

- Site Size-There is no maximum size for a site, but the applicant must justify the size of the site requested from both the business and environmental perspectives.

- Method of Site Disposition and Terms - A long-term lease is the disposition vehicle for commercial projects. Terms could go up to 65 years, however State policy has been for the initial period to be 15 years, with possibility of renewal in up to 15 year increments.

- Cost of the Lease - The CDUP processing fee for State marine waters is $2.5 \%$ of the project cost, with a limit of $\$ 2500$. Lease rents are a flat per acre fee of $\$ 100$ per acre per year or a percentage of gross sales $\left(1 \frac{1}{4} \%\right)$, whichever is higher.

- Bond for Facility Removal-The commercial lease requires a bond to remove the farm infrastructure and crop should the lease be terminated. The amount shall be sufficient to protect the public interest with the removal of all structures and stock.

\subsubsection{Discussion}

\section{Evolution of the Regional Approach}

Clearly the establishment of a regulatory mechanism for siting aquaculture in the U. S. EEZ has been controversial and a struggle, with members of the Congress, the current Administration and the public being on both sides of the issue, for and against. The U.S. has had a National Aquaculture Plan since 1980, but emphasis on open ocean aquaculture has only come to the forefront in the past 10 years, being fueled by: availability of mass culture hatchery technology for marine species, development of cage and mooring technology for open ocean conditions, growing seafood security concerns with growing reliance on imports (currently at 91\%), advances in understanding and monitoring environmental impacts of ocean farms, and well publicized successes with offshore culture in Europe and the Mediterranean.

Numerous efforts to establish a national regulatory system for the U.S. EEZ via national legislation have been frustrated by successful lobbying by environmental groups and actions by sympathetic members of Congress, as well as the U.S. industry being fragmented and not having a unified voice. A steady stream of public and private sector planning and policy studies over the past 10 years state it is in the 
best interests of the American people (the public interest) to develop open ocean aquaculture, yet only limited action has occurred.

Advantages of an overarching national regulatory system include: direct agency implementation of nationwide plans and policies, designation of a lead agency to issue and manage permits for all federal waters, opportunity for close coordination with all stakeholder agencies involved in the EEZ, and placement of the management entity in the nation's ocean management agency for efficient application of the best science to decisions. There appear to be no major disadvantages with this comprehensive, overarching approach.

Due to the political road blocks in Congress for national legislation, agency proponents utilized an obscure legal opinion that aquaculture is fishing and therefore the nation's principle fisheries management legislation, the MSA, as amended, could be used to move forward. MSA utilizes a regional approach through eight agency-stakeholder managed councils that prepare plans and policies and manage the fisheries in their jurisdiction, while working closely with NOAA. This community-based approach allows each region to develop a plan (or not) for aquaculture in federal waters and work with NOAA to promulgate rules to manage it.

The advantages of this regional approach include some of the same achieved by a national approach: the lead agency for fisheries would also be the lead agency for aquaculture, NOAA would still issue and manage site permits for the EEZ, and coordination would have a more regional focus.

Apparent disadvantages to this approach include: regionalizing planning and policy development could lead to differing approaches to implementation for each region (NOAA does have final approval on all plans and policies), plans and projects have to go through the "filter" of a diverse public-private management body (e.g., includes national and state agencies, commercial and recreational fishers, ocean recreation interests, cultural and environmental interests, etc.), the Councils are currently not staffed to manage commercial aquaculture in the EEZ and implementation and placement under the Fishery Councils adds another layer of bureaucracy to navigate.

\section{The Gulf Plan Rules, Concerns}

The adopted Gulf of Mexico Offshore Aquaculture Plan and pending Rules have been subject to intense stakeholder and public comment using Internet posting. Comments from a wide variety of stakeholders note a number of concerns and potential flaws in the Rules as currently written. The major concerns expressed by the aquaculture industry and potential investors are briefly highlighted below. Fortunately, if these concerns are realized as serious impediments to development, the Gulf Plan includes change processes to amend both the Plan and the Rules, hence the approach could be considered an Adaptive Management Approach to establishing a regulatory system for the U.S. EEZ. 


\section{Core Terms, Concerns}

- Production limitations-Placing limitations on total farm production for the region and on production for an individual farm could act as a disincentive to investment. The environmental characteristics should be used to establish the carrying capacity for an area as with U.S. states.

- Size limitations - Though there is not limit on farm size, dictating that a farm site must be twice as large as the combined area of allowable aquaculture systems to facilitate fallowing is inappropriate. Farms that want to use separate fallowing sites at their discretion would be penalized with excessive costs.

- Site disposition-There are concerns with the proposed method of site disposition, a permit rather than a lease. Legal questions have been raised as to whether a permit under the MSA enabling legislation is equivalent to a lease and can provide property rights and protections, tenure, exclusive use and capacity to secure financing and insurance.

- Terms of the permit-The concern is that the initial permit term of 10 years and a 5 year renewal are too short. Industry believes that these terms could be problematic for a large-scale commercial operation to fully build out and achieve profitability, as well as provide sufficient stability in rental costs and key terms to attract the large investment required. More reasonable and attractive terms would be and initial minimum period of 20 years and a minimum renewal period of 15 years, similar to several U.S. states.

\section{The Application, Concerns}

- Certified Broodstock - The applicant is required to certify that all broodstock or progeny of such broodstock were originally harvested form the Gulf of Mexico from the same population or sub-population where the facility is located. There are concerns that there is not sufficient reliable fish species distribution information for the Gulf to implement this provision and that the genetic sequencing is costly.

\section{Operating and Monitoring Requirements, Concerns}

- Time limits - There is a requirement to deploy $25 \%$ of allowable aquaculture systems approved for a site within 2 years and have fish stocked within 3 years of receiving the permit. Industry believes this time period should be at least 4 years for deployment and stocking, due to the many complexities of starting up both a large-scale hatchery and open ocean farm.

- Systems evaluation-Aquaculture systems utilized for growing fish would have to be evaluated by NOAA on a case-by-case basis. While the general 
requirement is reasonable in concept considering the frequency of storms in the Gulf of Mexico, the concern is it suggests the applicant may need to purchase expensive engineering analyses if not available from the vendor and construct computer and physical oceanographic models, and other complex documentation requiring extensive data collection over time, if not readily available from government sources.

- Offloading fish-Permittees are allowed to off load fish at Gulf dealers only between 6 a.m. and 6 p.m., local time. All fish landed must be maintained whole with heads and fins intact. The concern is this restriction will affect the farmer's ability to serve market needs and take full advantage of aquaculture's being able to offer predictable supplies.

- Other permits - In addition to the NOAA permit, two other permits are required to operate a fish farm in the EEZ; and ACOE Section 10 permit and an EPA NPDES permit. The concern is the rule requires applicants to secure these permits first before securing the NOAA permit, yet it is perceived the NOAA permit will have the most impact on the final structure, operation and maintenance of the farm. Several states issue the permit for the site first and subject to receiving the ACOE and NPDES permits, so that the major characteristics of the proposed farm are fairly firm before these other permit processes are concluded.

\section{Comparison with State Processes}

As with the regional aquaculture permit, siting of open ocean farms in Maine and Hawaii requires site disposition from the lead agency, as well as a Section 10 and NPDES permit. In contrast to the proposed regional approach, these successful states handle some of the core terms differently. To illustrate:

(a) The regional approach places limits on regional and individual farm production, while Maine has no limits on production but limits site size. Hawaii has no limits on production or site size, but the scale of a project must be justifiable and suitable for the oceanographic conditions.

(b) The regional approach uses a permit as the site disposition vehicle to provide the farmer some specified degree of site access and control. While Maine and Hawaii utilize a lease to clearly convey terms, tenure, property rights and protections and exclusive use for a public benefit of what was a public resource.

(c) The regional approach limits species to those managed by the Gulf Council. While Maine's experimental and standard leases have no native species restrictions and likewise there are no native species restrictions for Hawaii open ocean farms.

(d) The regional approach does not limit total site size, but requires a site be twice the size of that required by the aquaculture facility (cages, net pens, moorings) to allow for fallowing portions. While Maine has limits of 40 ha for its 
Standard lease and 1.62 ha for its experimental lease and Hawaii has no limits on lease size but scale must be justified.

(e) The regional approach utilizes a permit of 10 years duration and 5 years for each renewal period. While in Maine a lease uses terms of 3 years for the Experimental and 10 years for the Standard, and renewals are possible. In Hawaii a lease is also used that could go up to 65 years, though recent policy has been 15 years and 15 years for renewals.

(f) The regional approach costs a flat fee of $\$ 10,000$ and $\$ 1000$ annual fee, with each 5 year renewal costing $\$ 5000$. While in Maine, the Standard lease costs $\$ 1500$ or shellfish and $\$ 2000$ for finfish, plus $\$ 100$ an acre annual rent; with renewals of $\$ 1000$ for shellfish and $\$ 1500$ for finfish. In Hawaii the CDUP processing fee is $2.5 \%$ of the project cost, with a limit of $\$ 2500$. Lease rents are a flat per acre fee of $\$ 100$ per acre per year or a percentage of gross sales $\left(1 \frac{1}{4} \%\right)$, whichever is greater.

(g) The regional approach requires a bond for facilities removal. Both Maine and Hawaii have a similar requirement.

It remains to be seen if this as yet unapproved and untried regional approach to allow commercial aquaculture into the U.S. EEZ will be embraced by private industry, as the permitting and leasing processes have been in Maine and Hawaii.

\subsubsection{Case Study-Shellfish Farming in the Northeastern and West Coasts of the U.S., Recent Examples}

The regulatory regimes for offshore shellfish farming in the US vary depending on locale and the agencies involved. The regulatory process is quite new for most applicants and authorities so there is little precedent from which to build. Some states (e.g. Rhode Island and Maine) have established a "Limited Production Application" process which takes as little as 6 months, and allows a proponent to establish a small-scale demonstration of their intended farming design and practices. Other states do not have such provisions and require a substantial investment of time and money for permitting regardless of the size of the operation being proposed. Small offshore shellfish farms, mostly growing mussels have been permitted in the state waters of New Hampshire, Massachusetts, Rhode Island and Connecticut in the last 5 years.

Despite these promising developments in state waters (defined as within $3 \mathrm{~nm}$ of shore), recent experiences to permit shellfish farms in federal waters (3-200 nm from shore) off Massachusetts and California show that site selection, regulatory uncertainty, and monitoring requirements are a substantial challenge to offshore aquaculture development in the US. The following case histories illustrate that user conflicts and associated permitting requirements have resulted in substantial downsizing, relocation, and redesign of proposed activities despite the best efforts of project proponents to identify and avoid potential conflicts in advance. 


\subsubsection{Catalina Sea Ranch-First Farm Permitted in Federal Waters}

In California, Catalina Sea Ranch (CSR) engaged with the US Coast Guard and devoted substantial efforts towards understanding marine mammal avoidance when identifying its initial 405 hectare site for its mussel farm. Subsequently it was required to downsize to 40 ha and engage more fully with the State of California Coastal Commission (CCC), fishing interests, and the offshore oil and gas industry interests before identifying a site that effectively minimized conflicts with other offshore users.

CSR was issued a provisional Army Corps of Engineers (ACOE) permit under Section 10 of the Rivers and Harbors Act on July 17, 2012 (see also Sect. 3.2.4). The Rivers and Harbors Act was designed to permit marine construction projects while avoiding hazards to navigation. This provisional permit included a variety of expected permit conditions. A surprising and unprecedented permit requirement for ACOE approval and State Coastal Zone Management (CZM) agency concurrence was a monitoring plan for the seawater filtration effects, biodeposition, and changes in the abundance/distribution of non-native fouling organisms.

The permit was termed provisional because it was not valid and did not authorize the project to be carried out because, by Federal law, no permit can be issued until the State agency in charge of CZM consistency certification (the CCC) has concurred with the permit. To meet the concurrence requirements, it took another 18 months (January 2014) for the California Coastal Commission and CSR to agree to terms for a monitoring plan. Provisional permits may be also be issued until an applicant can satisfy a State's Section 401 Water Quality Certification. This was not necessary in this case as it is generally agreed that filter-feeding shellfish aquaculture produce a net benefit for water quality.

\section{Catalina Sea Ranch's Offshore Mariculture Monitoring Program}

Prior to commencement of construction (slated for early 2015) CSR must submit a Revised Offshore Mariculture Monitoring Program for approval by the Executive Director of the CCC. The Offshore Mariculture Monitoring Program is required to meet unprecedented environmental study, carried out by an independent entity approved by and reporting to the CCC for at least 5 years and funded by CSR. The monitoring must evaluate:

(i) Quantity, type, and distribution of biological materials from the shellfish facility (such as feces and pseudofeces, shell material, and fouling organisms) that accumulate on the seafloor below and in the vicinity of the facility, and it must evaluate any biochemical changes in the sediment and changes in biomass, diversity of benthic infaunal and epifaunal communities.

(ii) Response of fish, seabird, and marine mammal populations in the project area to the presence of the facility infrastructure, include estimates of the species 
diversity and abundance of the water column biota, including phytoplankton, zooplankton, and meroplankton.

(iii) Water quality in and around the facility including analysis of phytoplankton and particulate material filtration by the cultivated shellfish and release of nutrients such as ammonia nitrogen and phosphorus.

(iv) Type and amount of commercial and recreational fishing activity that occurs at and around the facility as well as compilation of all reports of lost or damaged fishing gear or catch (for which CSR may be libel) that occurs as a result of contact with the facility.

(v) Production of eggs and larvae from the cultivated non-native species, the regional dispersion of this reproductive material, and its contribution to the regional presence, persistence, and expansion of populations of these non-native species outside of cultivation.

(vi) Diversity and abundance of fouling organisms that establish on the shellfish cultivation facility, including its ropes, buoys, cables, cultivation structures, and cultivated shellfish.

These extraordinary monitoring measures contrast with any other existing shellfish farm in State waters in California. For example, a mussel farm, Santa Barbara Mariculture, has been operating $1.6 \mathrm{~km}$ offshore in California for over 10 years without any monitoring requirement or suspected environmental impact. No example of documented negative impact of shellfish farms in open or offshore waters are known anywhere else in the world.

\subsubsection{Massachusetts Case Studies-A Tale of Two Projects}

\section{Cape Ann Mussel Farm}

In 2012, a mussel farming project was proposed in federal waters 8 miles off Cape Ann by Salem State University, and funded by NOAA as a research demonstration project. One of objectives was to advance and further define the permitting process in Federal waters, and another was engage and train displaced fishermen in a new venture. In this case, 2 sites were chosen but one was abandoned due to conflicts identified early with the Stellwagen Bank National Marine Sanctuary nearby and its management plan that does not permit aquaculture within its boundaries.

Despite substantial collaboration and engagement with the capture fishing industry to identify the preferred site, there was potential conflict with commercial vessel traffic requiring that the longlines be deployed at $15.2 \mathrm{~m}$ below the ocean surface instead of $9.1 \mathrm{~m}$. The potential for marine mammal entanglement was a big issue, in both the CA and MA cases. Project proponents were unaware of these potential conflicts and/or mandatory permitting or consultation requirements that might require remediation or project alteration - in part due to a lack of data or prior permitting experience that would help predict and avoid these hurdles. 
Another issue that arose during the Massachusetts permitting process is that federal waters, in contrast to more coastal state waters, lack routine monitoring of Harmful Algal Blooms (HABs) that can result in offshore waters closed to shellfishing or farming due to potential for Paralytic Shellfish Poisons (PSP). In 2013, re-opening of the Northern and Southern Temporary PSP Closure Areas was not considered because there was no research or controlled experimental harvests conducted in these areas that would provide samples to indicate that the PSP toxin levels are below the regulatory limit. However, it was recently announced that as of January 2015, the Massachusetts Division of Marine Fisheries will be conducting testing of shellfish in the closed areas to re-open the fishing for gastropods (whelks, conchs, snails) and whole and roe-on scallops, and farmed mussels. Finally, after making the same concessions as described below a permit for the project was issued in January 2015.

\section{Nantucket Sound Mussel Farm}

In July of 2013, Santoro Fishing Corporation submitted an application to ACOE for a permit to commercially farm mussels in an 11.5 ha site $9.6 \mathrm{~km}$ offshore just east of the permitted Cape Wind farm in the Federal waters of Nantucket Sound. After a protracted permitting process described below, a permit was issued August 21, 2014 to deploy longlines for growing blue mussels (Mytilus edulis) and sugar kelp (Saccharina latissima). The principal reason that the permitting was prolonged hinged on perceived risks to protected species that migrate through the area.

NOAA Protected Resources Division (PRD) decided that they needed further information. The ACOE called a meeting in November 2013 of the permit applicants and the various NOAA regulatory interests (Essential Fish Habitat, Marine Sanctuaries, Protected Resources, Aquaculture, etc.) to foster exchange of information, concerns, and promote better understanding of the Nantucket Sound and Gloucester project proposals. Similar longline mussel operations have been operating in fully-exposed offshore state waters of California and New England for over 15 years without apparent impact or interference with protected species, such as whales and sea turtles. Despite this history, NOAA's PRD decided that they could not make a determination of "No effect" or "Not Likely to Adversely Affect" without reviewing a full biological assessment that addressed possible threats to protected species by the specific projects.

NOAA's PRD staff provided a guidance document for submitting a Biological Assessment. This started a confusing 9-month process involving exchanging drafts of the biological assessment with NOAA staff thru the permit coordinator at ACOE. Some of the confusion stemmed from the determination process of "effect", "not likely to adversely affect", or "no effect". It is the action agency (in this case ACOE) that makes this determination in order to initiate informal consultation. This was not 
clear to ACOE nor the applicant, and apparently was only made clear by PRD late in the process, after ACOE threatened to close the file because PRD's review process was taking too long.

After numerous correspondence through ACOE and concessions by the applicant, PRD indicated that the Nantucket Sound draft Biological Assessment contained elements with which they believed could lead to a determination of "Not Likely to Adversely Affect". Specifically, to prevent possible entanglement, the permit application was revised to include stiff sheathing on the vertical lines that connect the surface corner buoys to the submerged headrope. Also, the project would be developed in stages, with no expansion beyond the first stage, only 3 longlines, without further review by NOAA PRD and ACOE. Finally, NOAA PRD asked ACOE to initiate an "informal consultation" with the issuance of a permit letter and the final biological assessment to NOAA. Evidently a "formal consultation" under Section 7 of the Endangered Species Act is only initiated when there is likely to be an effect, and perhaps disagreement between parties about the suitability of a project. The confusing terminology surrounding the permit process's communication and consultation in its various forms (pre-informal, informal and formal) needs an explicit framework from which all parties can work through with transparency.

\subsubsection{Discussion}

The formal permitting process from time of filing the application to approval for the projects above varied from 13 months to more than 2 years. The timing of actual preparation of the permit application (consulting with various local, State and Federal constituents) may constitute another 3 to 6 months.

Early consultation is recommended with responsible agencies and data portals like the Northeast Ocean Data Viewer for maps and data for ocean site planning in the northeastern United States (Northeast Ocean Data Viewer 2014).

Applicants should meet with State and Federal fisheries resource managers and commercial fishing organizations and other ocean users to avoid potential conflicts with other marine activities. Applicants should also request a meeting with the Division heads (Protected Species, Aquaculture) of their regional NOAA fisheries office to discuss the need for and scope of a Biological Assessment. If necessary, a Biological Assessment template available on line will help to understand the process (IWGA 2014).

The permit application process for future mussel farms of similar designs should be much simpler to replicate for other sites based on the examples described above. As the government regulatory system becomes more familiar with the environmental impacts of mussel farms and well informed site selection decisions are made, uncertainties encountered by permit applicants should be reduced. 


\subsubsection{Case Study: Mussel Farming Off the English Coast; One Farmer's Experience}

\subsubsection{Introduction}

The following case study describes the practical procedures and requirements experienced in order to obtain the various permits and leases needed to establish a large scale, suspended culture mussel farm off the coast of South Devon, England.

It should be noted that the experience described is specific to shellfish aquaculture and it only relates to the legal framework in place in England during the application period of 2008-2010. Legislation has been modified since that date although the general procedure is still broadly similar.

The procedures for licensing finfish aquaculture in the UK have significant differences to those for shellfish. Aquaculture licensing within the 12 mile limit is a devolved matter in the UK and there are fundamental differences in procedures between the separate administrations of England, Scotland, Wales and Northern Ireland.

The license and lease requirements described here were those relevant to suspended culture mussel farming and differ from those that would be needed for seabed cultivation of mussels or other shellfish.

\subsubsection{Description of Farm}

Permission was granted in 2010 for a suspended culture mussel farm that will cover a total area of 1540 ha of Lyme Bay off the coast of South Devon, England. The farm will be divided into 3 separate areas; two of 600 ha and one of 340 ha. All three of the areas lie between 3.5 and $9 \mathrm{~km}$ from the adjacent coast.

The exposure of the farm areas to open sea conditions varies, with the distance to the nearest shore being $3.5 \mathrm{~km}$ to the North, $300 \mathrm{~km}$ to the South East and $7000 \mathrm{~km}$ to the South West. The depth of water varies gradually between 20 and $28 \mathrm{~m}$. The seabed is generally mud and shell.

The farm equipment specified in the permit and lease application consisted of 790 longlines spread evenly between the 3 areas. Each longline will be individually moored to the seabed at each end and measure $250 \mathrm{~m}$ from mooring to mooring with $150 \mathrm{~m}$ of each headline used to support culture ropes. The longlines will be moored using helical screw anchors with the headline supported 2-3 m below the surface using vertical spar shaped floats. The culture ropes will be the continuous looped New Zealand system with loops hanging up to $9 \mathrm{~m}$ below the headline.

The corners of each area will be marked by a yellow special mark navigation buoy topped with a St Andrews cross and a yellow flashing light visible at 2 miles.

Construction of the bulk of the farm will take 3-4 years and is being preceded by the operation of two small but commercial scale trial areas of 4 ha, each of which were established in 2013. 


\subsubsection{Legislatory Framework}

The legislation covering suspended culture shellfish farming in England provides for applications for farms in waters up to 12 nautical miles $(\mathrm{nm})$ beyond the coast. Historically, the few farms that have been established beyond the limits of estuarine waters have been small and close enough to the coast to come under the jurisdiction of Harbor Authorities (local authorities over close inshore waters that exist is some locations). For waters beyond $12 \mathrm{~nm}$, i.e. the EEZ, it is not clear what the legal mechanism would be for granting permits or leases and so far the process has not been tested in practice by the lodging of an application.

The case study describes the first application in English waters for what could be considered a fully offshore farm located in open ocean conditions. The leases, licenses and permits that were required for the establishment of this farm and the agencies involved were as follows:

- Consent to deposit equipment on the seabed, Marine and Fisheries Agency.

- Lease of the seabed, The Crown Estate.

- Authorization as an Aquaculture Production Business, Fish Health Inspectorate.

- Shellfish Harvesting Areas Classification, Food Standards Agency.

\subsubsection{Application Process}

\section{Informal Consultation}

As this application was the first of its type and was novel in terms of both its scale and location, the first stage of the application was to discuss the possibility of establishing the farm with the owners of the seabed, which in this case was the Crown Estate. The discussions established the likely terms and conditions of any lease and a list of the various third parties that would potentially be interested and/or affected by the establishment of the farm. The parties were then approached and the proposed development of the farm was discussed on an informal basis. This informal process took place over approximately one year.

\section{Coast Protection Act 1949; Section 34}

The deposit of the materials and equipment on the seabed to construct the farm required government consent under Section 34 of the Coast Protection Act 1949, which is principally concerned with hazards to navigation. This consent was administered by the Marine and Fisheries Agency (MFA) which was an executive agency of the UK government. (Note: In 2010 the MFA was replaced by the Marine Management Organization (MMO) and the need for a CPA Section 34 consent was replaced by a Marine License issued by MMO.) 
The application for consent gave full details of the location of the proposed farm areas, the equipment to be deposited and the design of the equipment, the schedule of construction, the operation methods and management procedures for the farm, and the likely gross cost of the project.

Details of the application were then circulated for individual consideration to statutory bodies with responsibility for:

- Natural environment-Natural England

- Historic and cultural environment-English Heritage

- Defense-Ministry of Defense

- Navigation-Maritime and Coast Guard Agency

- Local government-East Devon District Council, Devon County Council

- Fisheries-Department of Environment, Fisheries and Rural Affairs

- Fish and shellfish health-Fish Health Inspectorate

- Food standards-Food Standards Agency

- Water quality-Environment Agency

- Ownership of the seabed-The Crown Estate.

The application was also circulated to interested non-statutory bodies such as fishermen's organizations, local environment groups, angling clubs and sailing clubs for comment. The availability of the application was published in local newspapers and copies of the application were lodged at the East Devon District Council local government office to give the general public access to the proposal.

Responses from non-statutory consultees were collated after the 6 week time limit allowed for public comment and an extension for the consultation period was granted to the statutory bodies to enable an in-depth consideration of the implications for the natural environment.

Once all the responses were received by the MFA the applicant was given the opportunity to address any issues raised by the consultees and to make adjustments to the application where appropriate.

The issues raised included:

- Restrictions to navigation within the farm areas

- Restriction of access to commercial fishing within the farm areas

- The potential for environmental impacts and benefits within and beyond the farm areas

- The socio-economic effects on the regional and national economy

- Security of supply of seafood at UK and European Community level.

The MFA then considered all responses from the consultees and the applicant and made the judgement that the Secretary of State should issue a conditional consent. The process of application, consultation, consideration and decision took approximately 11 months. 


\section{Seabed Lease}

The area of seabed required for the three farms is the property of the Crown Estate. The Crown Estate issues leases on its property and charges a rent for its use but they also have a stewardship role and an obligation to manage and enhance the value of their coastal assets. This means that the Crown Estate encourages the development of sustainable aquaculture at appropriate locations. There was therefore a need to obtain a lease from the Crown Estate who reviewed potential impacts of the project to the natural environment and to other users of the marine resource.

The application for a seabed lease followed a similar pattern to the application for a CPA Section 34 Consent. The same groups were consulted and a similar period was given for responses to be submitted. The applicant was then given the opportunity to address any of the issues raised by the consultees and to make adjustments to the application where appropriate. The issues raised included the potential effects of increased sedimentation below the farm structures, the primary productivity and carrying capacity of the water body, the structural integrity of the equipment and the provision of a decommissioning bond.

The Crown Estate then considered all the responses from the consultees and the applicant and made the judgement to issue a conditional lease for the trial phases of the project with an agreement to issue a lease for the full project on successful completion of the trials. The process of lease application, consultation, consideration and decision took approximately 10 months.

\section{Aquaculture Production Business}

Under European Council Directive 2006/88/EC all member states must maintain a register of Aquaculture Production Businesses for the purposes of preventing the spread of the disease and controlling movements of aquaculture animals and products. In England and Wales the register is maintained by the FHI (Fish Health Inspectorate) which is a unit within CEFAS (Centre for Environment, Fisheries \& Aquaculture Science).

The FHI required the applicant aquaculture business to draw up a biosecurity plan, to maintain a record of movements on and off the farm premises, and to report and maintain a record of unusual mortalities. The business was then registered under Annex II of the Public register of Aquaculture Production Businesses in England and Wales.

\section{Shellfish Harvesting Area Classification}

Classification of harvesting areas is required and implemented in England and Wales under European Regulation 854/2004 before live bivalve shellfish are permitted to be placed on the market. The coordination of the shellfish harvesting area classification and monitoring programme in England and Wales is carried out by CEFAS on behalf of the Food Standards Agency (FSA). 
Classification of a harvesting area is determined by the extent to which the shellfish are contaminated by Escherichia coli. The sampling of the shellfish must take place from a position that represents the production area and the samples should represent the shellfish that will be placed on the market. For a production area with no history of production and no existing population of market sized shellfish, classification cannot take place until market sized shellfish have been produced. In this case study the farm was offshore and used suspended culture which meant that the farm had to be established and shellfish had to be grown in situ before classification could take place.

\subsubsection{Discussion of Current Licensing Process}

The case described above shows that in theory the basic procedure for gaining permission to establish and operate a suspended culture mussel farm in the offshore zone in England was relatively straightforward and no different to that for an inshore farm. In practice there was a great deal of difference and at nearly three years, the full process took considerably longer than would normally be experienced for an inshore application.

The key delays were brought about by the lack of experience and knowledge within the statutory agencies regarding the potential environmental and socio-economic impacts of a large-scale offshore mussel farm. This is not surprising as this application was the first of its kind, but the result was a lack of capability to arrive at timely and relevant decisions which contributed to extended delays in granting permission.

\section{Environmental Impact}

The issue of potential environmental impact centered on concerns over the effects of increased sedimentation and organic enrichment directly below the culture ropes and to what extent the sedimentation footprint of the farm would extend beyond the boundaries of the farmed areas.

Whilst there was no particular concern about the seabed below most of the farm areas, which had previously been impacted by towed fishing gear, there was concern about the potential impact on a marine Special Area of Conservation (mSAC) that is adjacent to one of the three sites. There was very little experience to provide reference on these issues as there were no UK precedents for a farm of this scale built in an offshore high energy environment, and few comparable operations were to be found elsewhere in the world.

A review was made of all the information available from other studies and this was coupled with assumptions on production rates, stocking densities and management practices on the farms. Sinking rates of mussel faeces and pseudo-faeces, depths, current velocities, wave induced turbulence, sediment re-suspension and assimilation rates were estimated. 
The review and estimates were presented to Natural England (NE) who acted as advisors on the natural environment to the MFA. This information enabled the applicant and NE to arrive at an adaptive management plan which entailed the applicant carrying out an environmental baseline study prior to development. The study covered a comprehensive range of parameters including biodiversity, species abundance, sediment and water chemistry, redox potential, sediment particle size distribution and hydrodynamics at a local and regional scale. The baseline study will be followed by further monitoring to detect any changes to the environment during development. This study will be carried out on the trial sites and on the first stages of development of the full commercial scale farm not adjacent to the mSAC. Results from these studies would then inform a decision on whether permission would be granted to develop the third site that is adjacent to the mSAC.

\section{Socio-Economic Impact}

The nature of the suspended culture mussel farm meant that a number of other activities would be physically excluded from the area, some would be curtailed and some would be enabled and possibly enhanced.

The principle marine activities in the area were:

- Fishing with mobile gear such as trawls and dredges

- Fishing with static gear such as pots, hand lines and set nets

- Leisure uses, i.e. angling, scuba diving and navigation for leisure vessels.

It was apparent that mobile gear would necessarily be excluded from the area, while fishing with static gear such as hand lines and angling, and scuba diving could continue to take place and could possibly be enhanced by the reef effect of the mussel ropes in the water column in an area where there was previously very little physical complexity and relief.

In reaching their positive decisions, the MFA and the Crown Estate reviewed the existing level of economic activity at the proposed areas and compared this with what could continue to take place on site together with the new economic activity that would be generated by the farm in terms of onshore, offshore and downstream employment.

The UK and the wider European Community currently relies heavily on imports and so also taken into account was the strategic need to improve security of supply of seafood and the fact that the establishment of this pioneering farm would provide information that would inform future offshore developments.

\subsubsection{Discussion-Future Regulation and Co-location of Offshore Aquaculture}

Marine aquaculture in most of its various forms is a relatively new activity that has to compete for limited space in the marine environment with more long term, 
established activities such as fishing, transport, leisure boating, aggregate extraction, power and communication cabling and defense, as well as the more hard to quantify services such as scenic amenity and nature conservation.

The current system of licensing marine aquaculture in England operates on a case by case basis where there is essentially a presumption against development and each proposal has to justify its application in terms of how it will either not affect existing activities or how it would be an improvement on existing activities. This has led to the alternative idea that licensing should be determined by marine plans with predetermined zones where there is a presumption for each activity.

Both of these approaches have their advantages and disadvantages and for the inshore zone where the needs of aquaculture are well defined and understood, either of these approaches can be made to work. However for the offshore zone, aquaculture is still in its infancy and the techniques, equipment, management practices and economics are not well developed and are likely to evolve over coming years. This means that the criteria by which offshore aquaculture is presently judged against other activities are likely to change and the rationale for placing aquaculture in a particular zone may prove to be inadequate in future years.

Co-location is often presented as a solution to this problem and there have been proposals and trials to co-locate aquaculture with a number of different activities worldwide. These include; the co-location and integration of different types of aquaculture at different trophic levels; co-location with reconstructed oyster reefs to enhance fisheries and biodiversity; co-location with structures such as marina pontoons, shore defenses or artificial reefs; and co-location with renewable energy installations or redundant oil and gas rigs. All of these have potential but all of them require an in-depth understanding of the individual needs of each activity before co-location could become a practicality.

Offshore mussel farming using suspended cultivation is regularly cited as a potential candidate for co-location with renewable energy structures, but currently there are no commercial examples in operation. The reasons for this are: partly because of the lack of an economic driver; partly because the technology of offshore mussel production is new and undeveloped; and partly because of the lack of a clear regulatory framework and operational protocols that would provide security for both of the co-location partners.

The economics of offshore mussel farming become more challenging the further offshore the farm is situated. The advantages are that the potential space resource for production increases, growth rates can improve, and diseases and anthropogenic pollution can decrease. The disadvantages are the increased cost of storm resistant equipment, the distance from shore base, the need for large expensive seagoing vessels and the lack of access during bad weather coupled with the difficulty of maintaining markets that require regular service. The production economics can also be rapidly altered by changes in markets for the mussels or changes in major costs such as fuel.

The technology of offshore mussel production is relatively simple in terms of equipment with most installations around the world consisting of a simple longline anchored at both ends and buoyed up to, or near to, the surface. The chief 
differences result from site specific conditions which determine such things as line geometry, mooring tensions, stocking density, rope spacing, seeding, harvesting and adjustment of buoyancy. The difficulty of perfecting each of these operations increases with exposure to open ocean conditions and it is likely that they would be further complicated by the need to integrate with the operational needs of a wind farm which are by their nature windy places.

Co-location of suspended culture offshore mussel farms with wind farm structures seems unlikely to be a viable option for mussel farmers in the UK under current economic conditions and would only seem to be likely if there was a regulatory imperative. This would need to be in the form of a compulsion, such as no development being allowed other than in wind farms, or in the form of an incentive such as development and operating costs being subsidized or long term price guarantees being given for product, as is the case for wind farm developers.

\subsection{Recommendations for Developing a Regulatory System}

Based on the review of seafood and energy trends, the status of standalone and co-located aquaculture and the Case Study experiences, recommendations are offered for consideration by countries, nation-states and local governments that have or want to establish a supportive regulatory system for developing commercial open ocean aquaculture. It is important to note in considering these recommendations that moving aquaculture into open ocean environments is in the early stages and initial approaches to regulation will evolve as technology improves and industry experience is gained.

\subsubsection{Planning a Regulatory System}

- Government aquaculture plans and policies should include exploration and encouragement of commercial-scale standalone and co-located with ocean energy production aquaculture farming in nearshore and open ocean locations. Successful plans, policies and regulation of nearshore projects can eventually lead to open ocean developments.

- While suitable species and technologies are evident for open ocean farming in some countries, the emerging interest in moving further offshore needs greater emphasis and encouragement through increased investment in research, development and commercial-scale demonstration projects (R, D, \& D). Ultimately, government sponsored R, D, \&D should foster engagement of the private sector to innovate and expand open ocean aquaculture, e.g., provide financial incentives to encourage private investment. 
- Ocean wind farms in open ocean environments are the best near-term opportunity for significant future co-location of aquaculture production. In particular, planned location of wind farms off major port cities, would also convey market advantages to aquaculture. However, the mutual benefits of co-location need to be successfully demonstrated.

- Government should incorporate long-term aquaculture and ocean energy development and site identification objectives and capabilities into emerging Marine Spatial Planning Programs. For example, both the United Kingdom and the U.S. are increasing efforts in this area (UKL 2014; NOC 2014).

- Government should examine the advantages and disadvantages of regulating open ocean aquaculture on a regional basis verses a nationwide, state or local basis.

- Government should give consideration to encouraging co-location of aquaculture with other activities that benefit society and the nearby communities; for example reconstructed oyster reefs to enhance fishing and biodiversity, marina pontoons, and shore defenses and artificial reefs.

\subsubsection{The Regulatory System}

- Government should establish a regulatory system for open ocean aquaculture that is reasonable, science-based, predictable, and cost efficient and does not act as a disincentive to development. An adaptive management approach should be used, so experience can foster changes and in particular allow for aquaculture as a co-located use of oil and gas and wind energy platforms.

- Government should establish a lead agency and highly placed designated office for aquaculture development, which includes open ocean farming, to advocate and facilitate development (Corbin and Young 1997; Cincin-Sain et al. 2005). The office would be the first point of contact for potential projects and help farmers and investors understand the regulatory system, as well as, be responsible for education of other agencies and the public about aquaculture science, business, and societal benefits.

- Government should work to reduce overlapping and redundant permit requirements and streamline regulatory processes where possible, for example when information requirements are the same for two required permits. Also consider establishing a One Stop Location where all the permits needed for open ocean aquaculture can be secured/tracked and applicants can work with one agency.

- Government should provide dedicated applicant assistance with site identification and help rule out sites that have major environmental and multi-use conflicts early on in the process. Also it should facilitate access by applicants to oceanographic and other environmental and economic information for site and business planning. 
- Government should emphasize stakeholder participation and input into the permit/license/lease process to identify and help applicants resolve conflicts early in the process. For example, government could facilitate stakeholder information meetings (e.g., informal and required public hearings) and use the Internet to promote widespread information availability for stakeholders.

- Government should consider the advantages and disadvantages of placing limits on the size and the volume of production for an open ocean site. While limits may seem appropriate initially to manage perceived risk, there should be process in the regulations to, in the future, increase or decrease or remove such limits, once site carrying capacity is demonstrated.

- Whatever the site disposition vehicle, permit, license, or lease, the governing legislation should clearly provide that the recipient has exclusive ownership of the stock and use of the area for farming, has clearly defined property rights and protections, and is not at a disadvantage in securing project financing and insurance.

- The regulatory system should provide permit, license, and lease terms (i.e., length of time) that are long enough for the aquaculture project to build out to an operational full scale and reach profitability. The suggested initial time period for an open ocean project is 15-20 years, with optional renewal time periods for projects in good standing of 15 years. Timeframes of this length will give the project a stable tenure and greatest opportunity to be successful, profitable and pay off any long-term loans.

- The regulatory system should identify allowable species for culture and incorporate economically important native species, and those introduced species that are established in the environment. Introduction of non-native species for aquaculture purposes should only be considered after extensive study of environmental risks and a public process to solicit input from stakeholders.

- Fees for permits or licenses and rents for leases should be set as a balance between cost recovery for administration of the regulatory process and a reasonable charge for the use of the public resource, so that establishing a farm is attractive to private investment. Governments could consider putting these revenues in a specially designated fund that supports further open ocean aquaculture research and development, e.g., Hawaii, U.S.A.

- Government should consider creating a separate regulatory process for open ocean aquaculture research and large-scale demonstration projects considering the emerging status of the industry. The information requirements and review process for these R, D, and D projects in the EEZ should be easier, quicker, and less complex than for a commercial project because these projects are smaller in scale, temporary, and short term.

- Government should require baseline environmental studies as part of the application process that are realistic, based on science, and can be carried out in a timely fashion at a reasonable cost. The likely inherent stability of the open ocean environment at any site should be considered in designing baseline studies and the potential positive impacts of the aquaculture project should also 
be reported, such as enhancement of recreational fishing by fish naturally aggregating around the farm.

- Government should craft environmental monitoring requirements for aquaculture projects to foster sustainable development that are based on accepted science and essential parameters and reasonable sampling frequencies. Further they should not be overly burdensome to a farm located in a highly exposed, turbulent, open ocean setting. When uncertainty exists for the potential project impacts and rigorous monitoring is initially required, farmers should have the opportunity to modify monitoring plans (e.g., sampling frequency and parameters required) when sample data, are found, for example, to not be changing at a high rate or are having insignificant impact on ambient conditions.

\section{References}

Alfred-Wegener Institute. (2014). Marine aquaculture technologies. Accessed November 3, 2014 from http://awi.de/en/reserch/new_technologies/marime_aquaculture_maritime_technologies_ and_iczm/

Alston, D., Cabarcas, A., Capella, J., Bennetti, J., \& Cortes, R. (2005). Environmental and social impact of sustainable offshore Cage culture production in Puerto Rican Waters (p. 206). Final Report. Washington, DC: NOAA.

American Oil and Gas Historical Society. (2014). History of offshore oil and gas drilling. Retrieved September 28, 2014, from http://aoghs.org

Anderson, J., \& Shamshak, G. (2008). Future markets for aquaculture products. In: R. Michael (Ed.), Offshore aquaculture in the United States: Economic considerations, implications, and opportunities (pp. 231-244). NOAA Technical Memorandum. Silver Springs, USA: USDOC

Angel, D., \& Edelist, D. (2013). Sustainable development of marine aquaculture off-the-coast and offshore-A review of environmental and ecosystem issues and future needs in the tropical zones. In A. Lovatelli, J. Anguillar-Manjarrez, \& D. Soto (Eds.), Technical Workshop Proceedings: Expanding mariculture farther offshore: Technical, environmental, spatial, and governance challenges (pp. 173-200). Rome, Italy: FAO.

Aquaculture Planning \& Advocacy. (2011). Hawaii Dept. of Agriculture (124 p). Retrieved September 15, 2014, from http://hdoa.hawaii.gov/ai/files/2013/03/Permits-and-RegulatoryRequirements-For-Aquaculture-in-Hawaii-2011-Final.pdf

Balsiger, J. (2009). Letter to Dr. Robert Shiff, Chairman, Gulf of Mexico Fishery Management Council from James Balsiger, Acting Assistant Administrator for Fisheries, NMFS, NOAA. September 3, 2009. Retrieved September 3, 2014, from http://sero.nmfs.noaa/sustainable_ fisheries/gulf_fisheries/aquaculture/

Bridger, C. J. (Ed.). (2004). Efforts to develop a responsible offshore aquaculture industry in the Gulf of Mexico. Ocean Springs, MS: Mississippi-Alabama SG Consortium.

Brown, L. (2009). Plan B 4.0: Mobilizing to save civilization. New York: W.W. Norton \& Comp. Inc.

Buck, B. H., Krause, G., \& Rosenthal, H. (2004). Extensive open ocean aquaculture development within wind farms in Germany: The prospect of offshore co-management and legal constraints. Ocean and Coastal Management, 47, 95-122.

Buck, B. H., Krause, G., Michler-Cieluch, T., Brenner, M., Buchlolz, C., Busch, J., et al. (2008). Meeting the quest for spatial efficiency progress and prospects of extensive aquaculture within offshore wind farms. Helgoland Marine Research, 62, 269-281.

Bush Administration. (2004). U.S. Ocean action plan. Washington, DC: NOAA. 
Callies, D. L. (2010). Regulating paradise: Land use controls in Hawaii. Honolulu, Hawaii: Univ. of Hawaii Press.

Cincin-Sain, B., Bunsick, S., Corbin, J., DeVoe, M., Eichenberg, T., Ewart, J., et al. (2005). Recommendations for an operational framework for offshore aquaculture in U.S. Federal Waters. Technical Report. Gerard J. Mangone Center for Marine Policy, University of Delaware.

Coastal Response Research Center. (2010). Technical readiness of ocean thermal energy conversion (OTEC). Durham, N.H.: University of New Hampshire.

Code of Federal Regulations. (2014). Permit, suspension, modification and denial. Retrieved November 2, 2014, from http://www.gpo.gov/fdsys/granule/CFR-2009-title15-vol3/CFR2009-title15-vol3-part904

Corbin, J. S. (2010). Sustainable U.S marine aquaculture, a necessity. Marine Technology Society Journal, 44, 7-21.

Corbin, J. S., \& Young, L. (1997). Planning, regulation, and administration of sustainable aquaculture. In J. Bardach (Ed.), Sustainable aquaculture (pp. 201-233). New York: John Wiley and Sons.

Crown Estate. (2014). What we do. Retrieved November 2, 2014, from http://www. thecrownestate.co.uk/coastal/what-we-do/

FAO. (2014). The State of World Fisheries and Aquaculture-Opportunities and challenges. Rome, Italy: FAO.

Firestone, J., Kempton, W., Krueger, A., \& Loper, C. (2005). Regulating offshore wind power and aquaculture: Messages from land and sea. Cornell Journal of Law and Public Policy, 14, 72-111.

Fletcher, K. (2004). Law and offshore aquaculture: A true hurdle or a speed bump. In C. Bridger (Ed.), Efforts to develop a responsible offshore aquaculture industry in the Gulf of Mexico: A compendium of offshore aquaculture consortium research (pp. 23-34). Ocean Springs, MS: Mississippi-Alabama Sea Grant Consortium.

Forster, J. (2013). A review of opportunities, technical constraints, and future needs of offshore mariculture-Temperate waters. In A. Lovatelli, J. Anguillar-Manjarrez, \& D. Soto (Eds.), Technical Workshop Proceedings: Expanding mariculture farther offshore: Technical, environmental, spatial, and governance challenges (pp. 77-100). Rome, Italy: FAO.

Friedman, T. (2008). Hot, flat, and crowded. New York: Straus and Giroux.

Global Wind Energy Council. (2014). Current status global offshore wind farms. Retrieved July 27, 2014, from http://www.gwec.net/global-offshore-current-status-future-products

GMFMC. (2014a). Offshore mariculture rule. Retrieved September 28, 2014, from http://www. gulfcouncil.org/index.php

GMFMC. (2014b). National offshore aquaculture Act 2007. Retrieved November 2, 2014, from http://www.gulfcouncil.org/fishery_management_plans/aquaculture_management. php\#Legislation

GMFMC \& NOAA. (2009). Final fishery management plan for regulating offshore marine aquaculture in the Gulf of Mexico. GMFMC and NOAA,

Harvard Law School Emmett Environmental Law and Policy Clinic, Environmental Law Institute \& The Ocean Foundation. (2012). Offshore aquaculture regulation under the clean water act. Retrieved September 5, 2014, from http://www.eli.org/sites/default/files/docs/cwa-aquaculture.pdf

Holmer, M. (2013). Sustainable development of marine aquaculture off-the-coast and offshore-A review of environmental and ecosystem issues and future needs in temperate zones. In A. Lovatelli, J. Anguillar-Manjarrez, \& D. Soto (Eds.), Technical Workshop Proceedings: Expanding mariculture farther offshore: technical, environmental, spatial, and governance challenges (pp. 135-172). Rome, Italy: FAO.

Hubbs Sea World Research Institute. (2003). The grace mariculture project. Carlsbad, CA: HSWRI.

Interagency Working Group on Aquaculture. (2014). Guide to federal aquaculture programs and services. Retrieved November 20, 2014, from https://www.whitehouse.gov/sites/default/files/ microsites/ostp/NSTC/federal_aquaculture_resource_guide_2014.pdf 
Jeffs, A. (2013). A review on the technical constraints, opportunities, and needs to ensure the development of mariculture sector worldwide-Tropical zone. In A. Lovatelli, J. Anguillar-Manjarrez, \& D. Soto (Eds.), Technical Workshop Proceedings: Expanding mariculture farther offshore: Technical, environmental, spatial, and governance challenges (pp. 101-134). Rome, Italy: FAO.

Kapetsky, J. M., Aguilar-Mayarrez, J., \& Jenness, J. (2013). A global assessment of potential far offshore mariculture development from a spatial perspective. FAO Fisheries and Aqua. Tech. Paper No. 549. Rome, Italy: FAO.

Knapp, G. (2013). The development of offshore aquaculture: An economic perspective. In A. Lovatelli, J. Anguillar-Manjarrez, \& D. Soto (Eds.), Technical Workshop Proceedings: Expanding mariculture farther offshore: Technical, environmental, spatial, and governance challenges (pp. 201-244). Rome, Italy: FAO.

Krop, L., \& Polefka, S. (2007). Open ocean aquaculture in the Santa Barbara Channel: An emerging challenge for the Channel Islands National Marine Sanctuary. Santa Barbara, CA: Environmental Defense Fund.

Lagerveld, S., Rockmann, C., Scholl, M. M., Bartelings, H., van den Burg, S. W. K., Jak, R. G., et al. (2014). Combining offshore wind energy and large-scale mussel farming: background \& technical, ecological and economic considerations. Wageningen, NL: IMARES.

Leschin-Hoar, C. (2014). Meeting San Diego's aquaculture cowboy, Don Kent of Hubbs Sea World Research Institute forges ahead with plans for large-scale, open ocean fish farm. Fish Farming News, 5, 10-13.

Lovetalli, J., Anguilar- Manjarrez, J., \& Soto, D. (Eds.). (2013). Expanding mariculture farther offshore: technical, environmental, spatial, and governance challenges. Rome, Italy: FAO.

Mee, L. (2006). Complementary benefits of alternative energy: Suitability of offshore wind farms as aquaculture sites. Plymouth, UK: Marine Institute-University of Plymouth.

National Marine Fisheries Service. (2013). Fisheries of the United States 2012-Current fishery statistics No. 2012. Silver Spring, USA: NOAA.

National Ocean Council. (2014). Marine spatial planning. Retrieved December 3, 2014, from http://www.whitehouse.gov/administration/eop/oceans/marine-planning

National Sea Grant Law Center. (2012). Offshore mussel culture operations: Current legal framework and regulatory authorities. Oxford, USA: National Sea Grant Law Center, University of Mississippi.

NOAA. (2008). Offshore aquaculture in the United States: Economic considerations, implications and opportunities. Washington, DC: NOAA.

NOAA. (2011). NOAA aquaculture policy. Washington, DC: NOAA. Retrieved August 14, 2014, from http://www.nmfs.noaa.gov/aquaculture/docs/policy/noaa_aquaculture_policy_2011.pdf

Northeast Ocean Data Viewer. (2014). Maps and data for ocean planning. Retrieved September 28, 2014, from http://www.northeastoceandata.org/viewer/

Open Blue Sea Farms. (2014). World's largest open ocean fish farm. Retrieved December 4, 2014, from http://www.openblue.com/

Percy, D., Heshamunda, N., \& Kuemlangan, B. (2013). Governance in marine aquaculture: the legal dimension. In A. Lovatelli, J. Anguillar-Manjarrez, \& D. Soto (Eds.), Technical workshop proceedings: Expanding mariculture farther offshore: technical, environmental, spatial, and governance challenges (pp. 245-262). Rome, Italy: FAO.

PEW Marine Aquaculture Task Force. (2007). Sustainable marine aquaculture: Fulfilling the promise, managing the risks. Takoma Park, MD: PEW Charitable Trust.

PEW Oceans Commission. (2003). America's living oceans: Charting a course for sea change. Takoma Park, MD: PEW Charitable Trust.

Sims, N. (2013). Kona Blue Water Farms case study: Permitting, operations, marketing, environmental impact, and impediments to expansion of global open ocean mariculture. In A. Lovatelli, J. Anguillar-Manjarrez, \& D. Soto (Eds.), Technical workshop proceedings: Expanding mariculture farther offshore: technical, environmental, spatial, and governance challenges (pp. 263-296). Rome, Italy: FAO. 
State of Hawaii. (2014). CDUA marine waters application. Retrieved October 10, 2014, from http://dlnr.hawaii.gov/occl/forms-2/

State of Maine. (2014). Marine aquaculture in Maine. Retrieved November 1, 2014, from www. maine.gov/dlnr/aquaculture/

Statista. (2014). Offshore oil and gas rigs in 2014. Retrieved May 28, 2014, from http://www. statista.com/rigs-worldwide-by-region/

Stickney, R., Costa-Pierce, B., Baltz, D., Drawbridge, M., Grimes, C., Phillips, S., et al. (2006). Towards sustainable open ocean aquaculture in the United States. Fisheries, 3, 607-610.

U.S. Commission on Ocean Policy. (2004). An ocean blueprint for the 21st Century. Washington, DC: USCOP

U.S. Dept. of Commerce. (2007). NOAA 10 year plan for marine aquaculture. Washington, DC: NOAA, USDOC

U.S. DOC. (2011). U.S. Dept. of Commerce Aquaculture Policy. Retrieved August 17, 2014, from www.nms.noaa.gov/aquaculture/docs/policy/doc_aquaculture_policy_2011.pdf

U.S. General Accounting Office. (2008). Offshore marine aquaculture: Multiple administrative and environmental issues need to be addressed in establishing a U.S. regulatory framework. Washington, DC: U.S. Government Accountability Office.

United Kingdom Legislation. (2014). Marine and coastal access Act, 2009. Retrieved December 2, 2014, from http://www.leislation.gov.uk/ukpga/2009/23/notes/contents

Upton, H., \& Buck, E. (2010). Open ocean aquaculture-CRS Report to Congress 7-5700. Washington, DC: Congressional Research Service

World Bank. (2013). Fish to 2030: Prospects for fisheries and aquaculture. Agriculture environmental discussion paper No. 3. Washington, DC: World Bank.

Open Access This chapter is licensed under the terms of the Creative Commons Attribution 4.0 International License (http://creativecommons.org/licenses/by/4.0/), which permits use, sharing, adaptation, distribution and reproduction in any medium or format, as long as you give appropriate credit to the original author(s) and the source, provide a link to the Creative Commons license and indicate if changes were made.

The images or other third party material in this chapter are included in the chapter's Creative Commons license, unless indicated otherwise in a credit line to the material. If material is not included in the chapter's Creative Commons license and your intended use is not permitted by statutory regulation or exceeds the permitted use, you will need to obtain permission directly from the copyright holder.

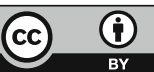

